\title{
Genetic Diversity and Screening of Rice (Oryza sativa L.) Genotypes for Drought Tolerance at Reproductive Phase
}

\author{
MS Pervin ${ }^{1 *}$, T Halder ${ }^{1}$, M Khalequzzaman ${ }^{3}$, M A Kader², T L Aditya² and R Yasmeen ${ }^{1}$
}

\begin{abstract}
Drought is a major abiotic constraint for growing rain-fed rice in Bangladesh. A total of 175 rice genotypes were evaluated using field-managed screening protocol to identify reproductive phase drought tolerant genotypes at Bangladesh Rice Research Institute, Gazipur, Bangladesh. Twelve morpho-physiological characters viz, growth duration, plant height, tiller number per plant, panicle number per plant, panicle length, filled grain number per plant, sterility percentage, filled grain weight per plant, 1000 grain weight (TGW), straw weight per plant, harvest index (HI) and percent yield reduction were recorded. Multivariate analysis was carried out by using software Genstat 5.5 to measure genetic divergence among the rice genotypes. In total 175 genotypes were constellated into ten clusters in which the cluster I exhibited maximum genetic distances from cluster $\mathrm{V}$ and the lowest genetic distance was between cluster II and X. Inter-cluster distances were higher than the intra-cluster distances suggesting wider genetic diversity among the genotypes of different clusters and homogeneity among the genotypes within the cluster. Among the 12 studied characters percent yield reduction contributed maximum towards total divergence in the genotypes, which revealed that these parameters contributed more to grain yield under drought stress. The genotypes of cluster I namely Canthi bakla (BRRI Genebank Acc. No. 7279), Nizersail (BRRI Genebank Acc. No. 7281), Hashim (BRRI Genebank Acc. No. 7283), Uricheora (BRRI Genebank Acc. No. 7311), Goura Kajol (BRRI Genebank Acc. No. 7312), Chini Sail (BRRI Genebank Acc. No. 7343), Tall Biruin (BRRI Genebank Acc. No. 7355), Sakkar Khora (BRRI Genebank Acc. No. 7506) and Boaincha Biruim (BRRI Genebank Acc. No. 7573) performed better under drought stress, which could be used in the crossing programme as donor parent for the development of variety.
\end{abstract}

Key words: Genetic distance, drought stress, morpho-physiological characters, multi-variate analysis, yield reduction

\section{INTRODUCTION}

Drought is a common feature in Bangladesh especially in dry season (Winter and Premonsoon), which causes a substantial reduction of rice yield. It occurs mainly for uneven distribution of rainfall and thus, north-western part of the country is treated as drought-prone (Pervin, 2015). Rice is more susceptible to drought than other cereals. Drought can affect rice plant in any growth stage (Yoshida, 1981). However, T. Aman cultivars usually suffer from drought stress at reproductive and /or early ripening phase resulting poor yield (Pervin, 2015). Rice plant is most sensitive to water stress from panicle initiation to heading stage
(Yoshida, 1981). Tuong et al. (1995) reported that the reproductive stages such as panicle initiation, panicle development, flowering and anthesis, meiotic development of gametes, fertilization and grain filling are sensitive to water stress, which cause spikelet sterility and rice yield loss. A limited water supply at panicle initiation stage causes $100 \%$ and $93 \%$ spikelet sterility in variety BR11 and BR22 respectively (BRRI, 1991). Reyniers et al. (1982) reported that irreversible damage is caused when water deficit occurs during heading and flowering. Most of the high yielding varieties developed so far are not bred specifically for drought situation. Traditional landraces are important reservoirs of many valuable traits (Hanamaratti

${ }^{1}$ Plant Physiology Division. ${ }^{2}$ Plant Breeding Division and ${ }^{3}$ GRS Division, Bangladesh Rice Research Institute, Gazipur 1701, Bangladesh.

*Corresponding authors' E-mail: pervinsalma@yahoo.com 
et al., 2008). Generally, landraces are highly adapted to adverse environment and also have varying levels of resistance to biotic and abiotic stresses (Li et al., 2004). Bangladesh is a land of rice and it has a lot of landraces, which may endure drought sufficiently. Study of diverse genotypes of a crop is necessary to assess their performances, which help to develop a new variety suitable for commercial cultivation. Grouping or classification of genotypes based on suitable scale is quite imperative to understand the usable variability existing among them. Selection of suitable genetically diverse parent to develop heterotic combinations can be facilitated by determining genetic divergence among them. But there is a little work on the analysis of genetic divergence of land race genotypes in relation to drought stress in Bangladesh context. So, the following investigation was carried out to find out the genetic divergence of BRRI rice germplasm and evaluate them for identification of drought tolerant donor.

\section{MATERIALS AND METHODS}

In total 175 rice germplasm including BRRI dhan56 and BRRI dhan57 were studied at BRRI farm, Gazipur, Bangladesh during T. Aman season 2015. Field-Managed Screening protocol (IRRI, 2008) was followed for drought screening. The experiment was conducted in two sets where the $1^{\text {st }}$ set was grown under well-watered condition as control and the $2^{\text {nd }}$ set under stress condition. Stress was initiated four weeks after transplanting in which field was drained out properly for not allowing any standing water until maturity. The experiment was laid out in Alpha lattice design with two replications. The perch water table depth and soil moisture was measured daily. Data on growth duration, plant height, tiller number per plant, panicle number per plant, panicle length, filled grain number per plant, sterility percentage, filled grain weight per plant, TGW, straw weight per plant and HI were recorded. The percent yield reduction of tested entries was calculated by comparing rice yield of stress plant with control plant.

\section{Statistical analysis}

Mean data for each character were subjected to multivariate analysis viz Principle Component Analysis (PCA), Principle Coordinate Analysis, Non-hierarchical Clustering and Canonical Variate Analysis using Genstat 5.5 [Release 4.1 (PC/Windows NT] (Mahalanobis, 1936; Jager et al., 1983; Digby et al., 1989).

\section{RESULT AND DISCUSSION}

\section{Rainfall pattern during experimental period}

Flowering of the tested genotypes started from $2^{\text {nd }}$ week of October to $3^{\text {rd }}$ week of November. So, before starting flowering ie during booting stage crop did not receive any rain water at least 13 days although $27.8 \mathrm{~mm}$ and $5.6 \mathrm{~mm}$ rainfall was occurred on $2^{\text {nd }}$ and $3^{\text {rd }}$ week of October respectively (Fig. 1).

\section{Water table depth}

The water table depth was below $30 \mathrm{~cm}$ from the soil surface at eight days after drainage of water, while it was about $72 \mathrm{~cm}$ for 13 days after drainage (Fig. 2). After that it was again decreased due to rainfall. At 30 days after withholding of water there was no water in the PVC pipe ie the water table depth was around $80 \mathrm{~cm}$ below the soil surface.

\section{Soil moisture status}

The average soil moisture of the experimental plot was 20.2 to $34.8 \%$ during booting to flowering stage (Fig. 3). However, the soil moisture was more than $30 \%$ only eight days, which was not consecutive. Consequent crop experiences drought stress at reproductive stage.

\section{Morpho-physiological characters}

Significant variations were recorded among the genotypes for all the 12 characters. Table 1 presents latent roots (Eigen values) of 12 principal component axes and percentage of total variations accounted for them obtained from the principal component analysis (PCA). The result revealed that the first axis largely accounted for the variation among the genotypes (95.57\%) 


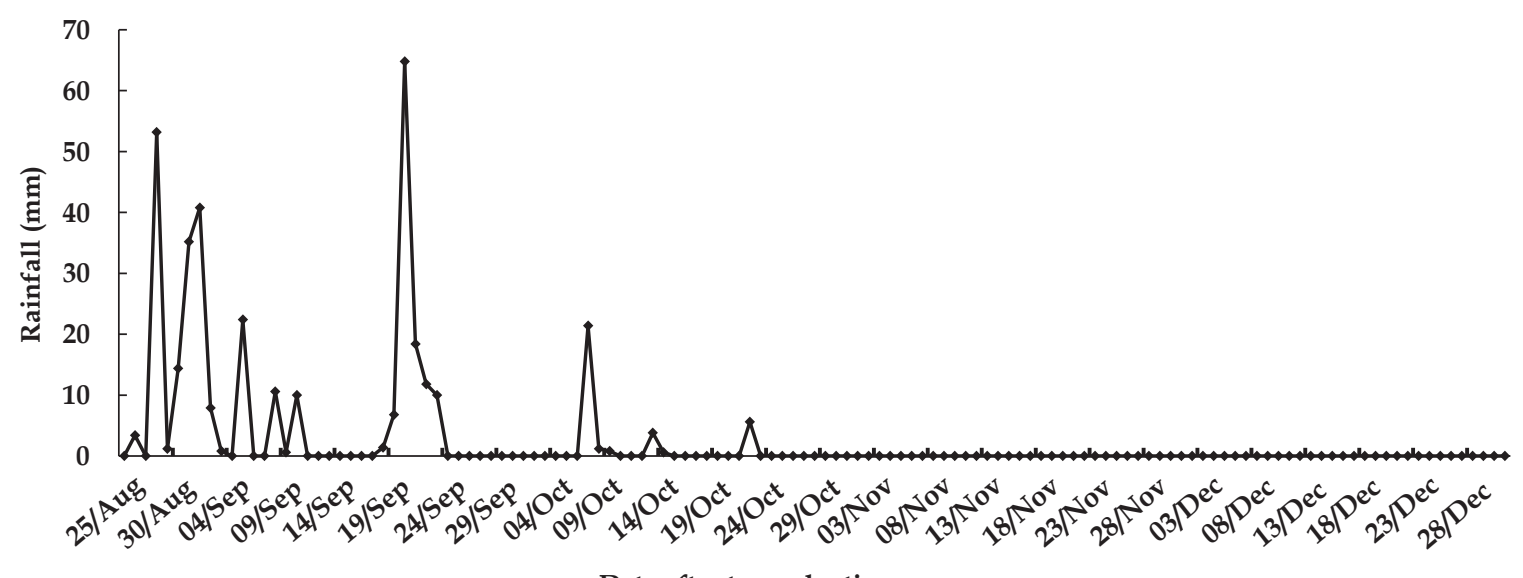

Fig. 1. Daily rainfall at Gazipur during T. Aman 2015.

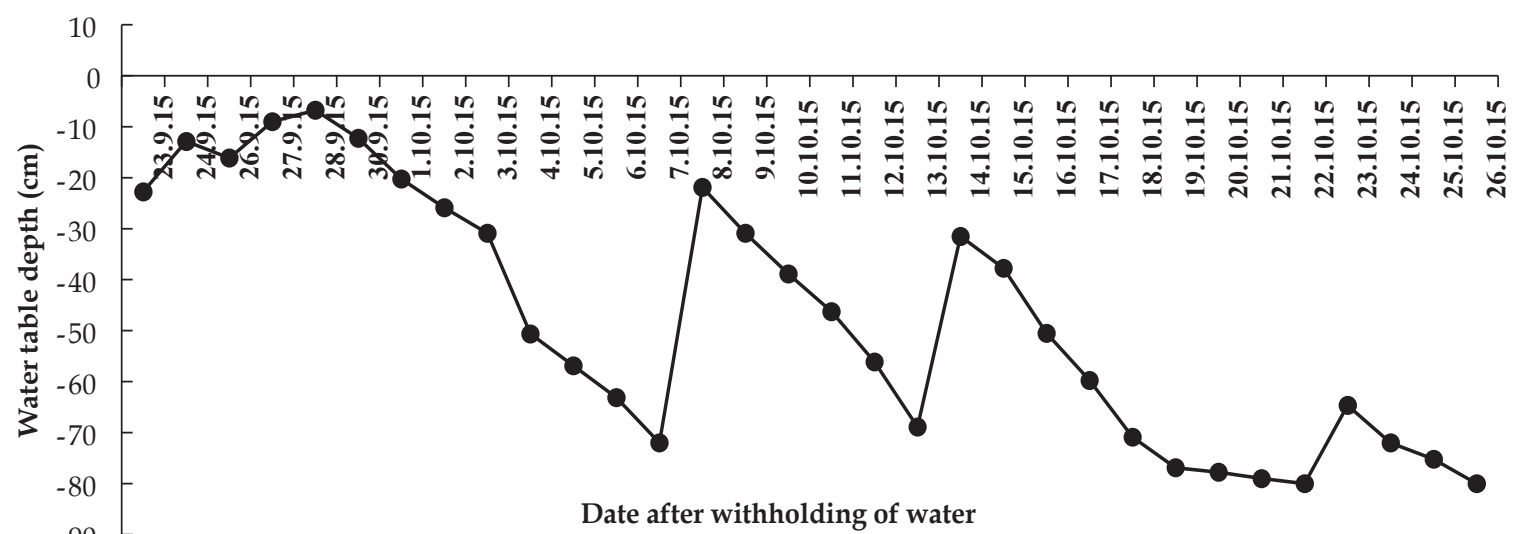

Fig. 2. Water table depth in stress field during T. Aman 2015.

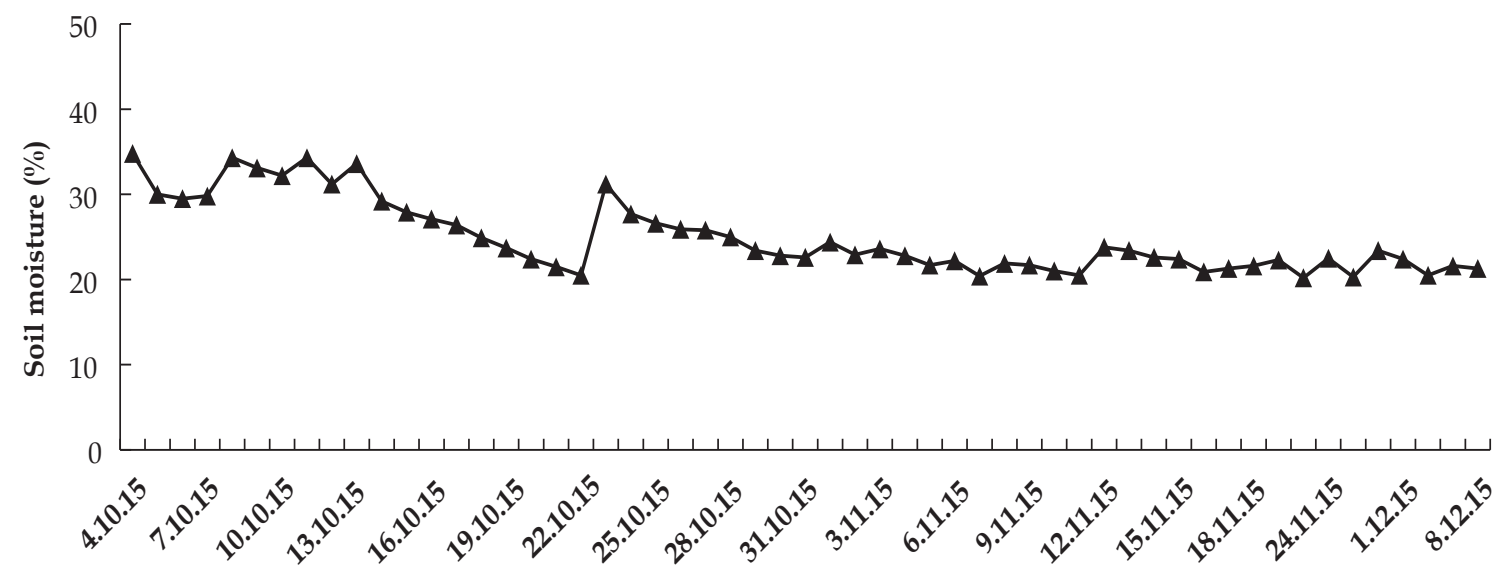

Date after withholding water

Fig. 3. Soil moisture at experimental plot. 
Table 1. Latent roots (Eigen values) and their variations in 12 morpho-physiological characters of 175 rice genotypes.

\begin{tabular}{cccc}
\hline Principal component axe & $\begin{array}{c}\text { Latent root } \\
\text { (Eigen value) }\end{array}$ & Percentage of variation & Cumulative \% of variation \\
\hline 1 & 10927110 & 95.57 & 95.57 \\
2 & 414812 & 3.63 & 99.20 \\
3 & 51080 & 0.45 & 99.65 \\
4 & 17531 & 0.15 & 99.80 \\
5 & 12180 & 0.11 & 99.91 \\
6 & 5561 & 0.05 & 99.96 \\
7 & 3503 & 0.03 & 99.99 \\
8 & 1132 & 0.01 & 100.00 \\
9 & 553 & 0.00 & 100.00 \\
10 & 441 & 0.00 & 100.00 \\
11 & 62 & 0.00 & 100.00 \\
12 & 0 & 0.00 & 100.00 \\
\hline
\end{tabular}

followed by the second axes $(3.63 \%)$. The first two axes accounted about $99 \%$ of the total variations among the 12 characters describing 175 genotypes of rice.

The $\mathrm{D}^{2}$ values ranged from 0.198 to 3.638 and PCA scores also indicated a high degree of genetic diversity among the genotypes (Data not shown). On the basis of $\mathrm{D}^{2}$ analysis, 175 genotypes of rice were grouped into ten clusters (Table 2). Maximum number of genotypes (25) were included in cluster VII followed by cluster X (24). Cluster V included the minimum number of genotypes (8). Cluster I, II, III, IV, VI, VIII and IX included 9, 20, 15, 17, 23, 14 and 20 genotypes respectively. Table 3 presents the mean values for all the 12 characters along with the marking of the highest $(\mathrm{H})$ and the lowest (L) for each of the cluster. Differences in cluster mean existed for all the characters were studied. In this study, cluster I had the most tolerant genotypes possessing the lowest mean value for percent yield reduction (31.1\%) and sterility percentage $(33.9 \%)$. This group had the highest average in comparison with the other groups considering many traits such as tiller number per plant (14.1), panicle number per plant (12.6), panicle length $(24.3 \mathrm{~cm})$, filled grain number per plant (1166.5), filled grain weight per plant (17.9 g), straw weight per plant (31.4 g). Regarding
$\mathrm{HI}$, it possesses the second highest value (0.34). Similarly, the genotypes of cluster III showed better performance than the other groups. The percent yield reduction was also the lowest in this cluster $(31.2 \%)$ and sterility percentage was below 50\% (39.6\%). Considering traits such as filled grain number per plant (930.8), filled grain weight per plant (16.8 g) and straw weight per plant $(28.4 \mathrm{~g})$ this cluster had the second highest average and regarding HI (0.35) this cluster had the highest average among all clusters. The mean values of other characters were also within desirable range in cluster I and III. In contrast to I and III, cluster V had the highest yield reduction $(60.0 \%)$ and sterility percentage (71.1\%). In respect of panicle length $(21.4 \mathrm{~cm})$, filled grain number per plant (179.2), filled grain weight per plant $(6.7 \mathrm{~g})$ and $\mathrm{HI}(0.20)$, it had the lowest mean value. Similar performance was also observed in cluster IX. So the genotypes of cluster $\mathrm{V}$ and IX were sensitive to drought stress. Hanamaratti et al. (2008) also identified some landraces as good donors of drought tolerance for future breeding programme.

The canonical variate analysis, complementary to Mahalanobis's D2 statistics, was carried out to obtain the cluster distances (Mahalanobis's $\mathrm{D}^{2}$ values) that indicated the index of genetic diversity among them. Theinter- 
Table 2. Distribution of $\mathbf{1 7 5}$ rice genotypes in different clusters through GENSTAT software on the basis of $\mathbf{1 2}$ morphophysiological characters.

\begin{tabular}{|c|c|c|c|}
\hline $\begin{array}{c}\text { Cluster } \\
\text { no. }\end{array}$ & $\begin{array}{l}\text { BRRI Genebank Acc. no. } \\
\text { of entry }\end{array}$ & $\begin{array}{l}\text { No. of } \\
\text { population }\end{array}$ & Genotype \\
\hline I & $\begin{array}{l}7279,7281,7283,7311,7312 \\
7343,7355,7506,7573\end{array}$ & 9 & $\begin{array}{l}\text { Canthi Bakla , N. Sail, Hashim, Uricheora, Goura Kajol, } \\
\text { Chini Sail, Tall Biruin, Sakkar Khora, Boaincha Biruim }\end{array}$ \\
\hline II & $\begin{array}{l}7313,7318,7349,7352,7356 \\
7497,7516,7536,7564,7589 \\
7596,7604,7612,7614,7615 \\
7618,7621,7637,7855,7866\end{array}$ & 20 & $\begin{array}{l}\text { Kalokathi Jana, BR11, Ronger Gura, Mohu Madab, Minna } \\
\text { Sail, Sada Kumari, Ajal Digha, Kala Biruin, Vaolo, Kaika } \\
\text { Biruin (Sada), Khagira, Gabra, Bahori Mota, Monor, Kudi } \\
\text { Agroni, Montoysa, Kutiagni Dhan, Kalo Sail, Tepairri, } \\
\text { Benapol (Brown). }\end{array}$ \\
\hline III & $\begin{array}{l}\text { 7309, 7314, 7321, 7332, 7344, } \\
\text { 7345, 7521, 7547, 7551, 7571, } \\
\text { 7583, 7597, 7859, 7864, BRRI } \\
\text { dhan56 (ck) }\end{array}$ & 15 & $\begin{array}{l}\text { Kalo Dhan, Balam, BRRI dhan53, Suganph Dhan, Rash } \\
\text { Mala, Chini Sagar, Kali Binni, Bina Sail, Kali Jira (Lal), } \\
\text { Deshi Biruir, Khama, Gasta, Kalan Pajam, Hogla Pata, } \\
\text { BRRI dhan56 (ck) }\end{array}$ \\
\hline IV & $\begin{array}{l}7341,7347,7357,7514,7524 \\
7555,7556,7562,7575,7580 \\
7588,7599,7617,7630,7643 \\
7857,7865\end{array}$ & 17 & $\begin{array}{l}\text { BR8922-4-4-4, Malsira, Biruin, Paijam, Biroin, Pak Biruin, } \\
\text { Mikal Biruin, Kat Lahi, Neer Dhan, Babusail, Basabo, } \\
\text { Gobioha Vhog, Chikon Dhan, Bash Moti, Jamai Kul, } \\
\text { Hasina Chikon, Chini Kanai }\end{array}$ \\
\hline $\mathrm{V}$ & $\begin{array}{l}\text { 7327, } 7340,7504,7511,7513 \\
7537,7613,7631\end{array}$ & 8 & $\begin{array}{l}\text { BR7155-20-1-3, BR6926-1-1-1-3-2, Kakchi Mota, Baro Sail, } \\
\text { Akhni Sail, Me-Dhan, Kala Mota, Bambu Dhan }\end{array}$ \\
\hline VI & $\begin{array}{l}\text { 7307, 7316, 7317, IR64, 7328, } \\
7342,7346,7503,7539,7541 \\
7550,7565,7569,7572,7587 \\
7603,7611,7619,7620,7628 \\
7636,7854,7861\end{array}$ & 23 & $\begin{array}{l}\text { Dakhanalal Dhan, Sakkr Khana, Kala Mota, IR64, Guti } \\
\text { Swarna, Tulsi Mala, Kajlo Jira, Kali Satia, Mekli Biruin, } \\
\text { Bogla Biruin, Pasu Sail, Bania Chor, Jora Bapail, Chini } \\
\text { Gura, Mondol, Tulai Pangi, Bon Hum, Chtrisail, Holud } \\
\text { Mota, Mowman Dhan, Ghurum, Shibjata, Nona Khorchi }\end{array}$ \\
\hline VII & $\begin{array}{l}7277,7278,7284,7285,7305 \\
7326,7333,7334,7350,7354 \\
7496,7499,7505,7525,7526 \\
7549,7553,7554,7560,7574 \\
7579,7600,7605,7648,7863\end{array}$ & 25 & $\begin{array}{l}\text { Quchchaly, Nathe Ngepru, NR-1190, Radha, Kalo Aus, } \\
\text { BR7770-5 (Nils), Proua-7, Fajla (Nawgan), Chini Kanai, } \\
\text { Jhoria, Jol Kumrri, Dudkalam, Kali Jira, Modhu Madhab, } \\
\text { Guar Chhora, Bauras, Tri-Dhan, Badsha Bhog, Haitta } \\
\text { Binni, Goarchoi, Rosaiya Binni, Dopa, Aman Chala, Boro } \\
\text { Bajal, Khejurchori }\end{array}$ \\
\hline VIII & $\begin{array}{l}\text { 7276, 7282, 7320, 7500, 7559, } \\
\text { 7566, 7576, 7601, 7602, 7610, } \\
\text { 7633, 7646, 7858, BRRI } \\
\text { dhan } 57\end{array}$ & 14 & $\begin{array}{l}\text { Ranga Binni, Hashim, BRRI dhan52, Sakkar Khana, } \\
\text { Modhu Binni, Lahi, Munsi Biruin, Guti Swarna, Danaguri, } \\
\text { Parijat, Lohagura, Hijol Dhiga, Swarna Lata, BRRI dhan57 }\end{array}$ \\
\hline IX & $\begin{array}{l}7300,7329,7348,7353,7501 \\
7522,7523,7527,7530,7535 \\
7563,7590,7608,7622,7626 \\
7634,7635,7639,7642,7645\end{array}$ & 20 & $\begin{array}{l}\text { Laxmi Digha, Bpt-5204, Nour Sail, Lotma, Sada Mota, Sar } \\
\text { Binni, Chenger Muri, Beru Sail, Sada Biruin, Rumu Sail, } \\
\text { Kaitta, Kala Biruin, Kajal Hai, Moina Moti, Boleshwas, } \\
\text { Holde Mota, Pathar Kuchi, Gaindha, Gachi, Dinga Mony }\end{array}$ \\
\hline$x$ & $\begin{array}{l}\text { 7335, 7351, 7498, 7502, 7507, } \\
7517,7519,7529,7532,7540 \\
7545,7577,7578,7585,7607 \\
7609,7616,7623,7624,7632 \\
7640,7649,7852,7853\end{array}$ & 24 & $\begin{array}{l}\text { Kajal (Nawgon), Parabat Jira, Lal Chikon, Lamba Vojon, } \\
\text { Khato-Irri, Super Meni, Birol Sail, Lati Sail, Kalo Birun, } \\
\text { Nijersail, Swarna Mosori Bhahu Bal, Sini Binni, Satkata } \\
\text { Binni, Chanda Binni, Jamli Mota, Buroa Badhe, Khoiya } \\
\text { Mota, Kapia Thuti Dhan, Balam, Changai Dhan, Baboni, } \\
\text { Jhinuk Mala, Rateil, Munsur }\end{array}$ \\
\hline
\end{tabular}


Table 3. Intra-cluster means for 12 morpho-physiological characters in 175 rice genotypes.

\begin{tabular}{|c|c|c|c|c|c|c|c|c|c|c|}
\hline \multirow{2}{*}{ Character } & \multicolumn{10}{|c|}{ Cluster number } \\
\hline & I & II & III & IV & $\mathrm{V}$ & VI & VII & VIII & IX & $\mathrm{X}$ \\
\hline $\begin{array}{l}\text { Growth duration } \\
\text { (day) }\end{array}$ & 128.4 & 127.9 & 126.4 & 128.2 & 130.8 & $\begin{array}{c}131.3 \\
(\mathrm{H})\end{array}$ & $\begin{array}{c}125.1 \\
(\mathrm{~L})\end{array}$ & 125.2 & $\begin{array}{c}131.3 \\
(\mathrm{H})\end{array}$ & 130.8 \\
\hline Plant height $(\mathrm{cm})$ & 140.0 & 135.1 & 136.1 & 127.2 & $\begin{array}{c}115.3 \\
(\mathrm{~L})\end{array}$ & 132.8 & $\begin{array}{c}160.6 \\
(\mathrm{H})\end{array}$ & 123.6 & 121.3 & 121.3 \\
\hline Tiller no./plant & 14.1 & $\begin{array}{l}12.3 \\
(\mathrm{~L})\end{array}$ & 13.0 & 13.6 & $\begin{array}{c}12.3 \\
(\mathrm{~L})\end{array}$ & 13.1 & 12.8 & 12.8 & 12.6 & 12.5 \\
\hline Panicle no./plant & $\begin{array}{l}12.6 \\
(\mathrm{H})\end{array}$ & 10.8 & 11.3 & 11.7 & 11.0 & 11.4 & 11.0 & 10.9 & $10.6(\mathrm{~L})$ & 10.9 \\
\hline Panicle length $(\mathrm{cm})$ & $\begin{array}{l}24.3 \\
(\mathrm{H})\end{array}$ & 22.9 & 23.2 & 23.3 & $\begin{array}{c}21.4 \\
(\mathrm{~L})\end{array}$ & 22.8 & 23.5 & 23.0 & 22.5 & 22.3 \\
\hline $\begin{array}{l}\text { Filled grain (no./ } \\
\text { plant) }\end{array}$ & $\begin{array}{c}1166.5 \\
(\mathrm{H})\end{array}$ & 444.2 & 930.8 & 509.7 & $\begin{array}{c}179.2 \\
(\mathrm{~L})\end{array}$ & 583.1 & 802.5 & 689.2 & 298.5 & 382.6 \\
\hline$\%$ sterility & $33.9(\mathrm{~L})$ & 49.5 & 39.6 & 51.0 & $\begin{array}{l}71.1 \\
(\mathrm{H})\end{array}$ & 43.6 & 39.8 & 42.5 & 60.3 & 52.6 \\
\hline $\begin{array}{l}\text { Filled grain wt } \\
\text { (g/plant) }\end{array}$ & $\begin{array}{r}17.9 \\
(\mathrm{H})\end{array}$ & 11.6 & 16.8 & 9.6 & $\begin{array}{l}6.7 \\
(\mathrm{~L})\end{array}$ & 12.4 & 14.8 & 12.7 & 7.1 & 8.8 \\
\hline TGW (g) & $\begin{array}{c}15.2 \\
(\mathrm{~L})\end{array}$ & 27.7 & 18.8 & 22.3 & $\begin{array}{c}33.5 \\
(\mathrm{H})\end{array}$ & 23.1 & 20.1 & 19.2 & 23.3 & 24.9 \\
\hline Straw wt (g/plant) & $\begin{array}{l}31.4 \\
(\mathrm{H})\end{array}$ & 26.8 & 28.4 & 23.0 & 27.1 & 27.5 & 25.8 & $\begin{array}{l}22.6 \\
(\mathrm{~L})\end{array}$ & 24.2 & 22.7 \\
\hline HI & 0.34 & 0.28 & $\begin{array}{l}0.35 \\
(\mathrm{H})\end{array}$ & 0.26 & $\begin{array}{c}0.20 \\
(\mathrm{~L})\end{array}$ & 0.29 & 0.33 & 0.34 & 0.21 & 0.26 \\
\hline$\%$ yield reduction & $\begin{array}{c}31.1 \\
(\mathrm{~L})\end{array}$ & 45.1 & 31.2 & 49.9 & $\begin{array}{c}60.0 \\
(\mathrm{H})\end{array}$ & 36.6 & 34.4 & 36.6 & 59.5 & 53.5 \\
\hline
\end{tabular}

Note: $\mathrm{H}=$ Highest average value and $\mathrm{L}=$ Lowest average value.

cluster distances were higher than the intracluster distances in all of the cases reflecting wider diversity among the genotypes of the distant group (Table 4). Similar results were also suggested by Rahman etal. (1998) in wheat. The intra-cluster distances were low for all the 10 clusters with the range 0.7918 in cluster IX and 1.2673 in cluster VII that indicated the homogeneous nature of the genotypes within the clusters. Regarding inter-cluster distance, cluster I showed maximum genetic distance (30.42) from cluster $V$ followed by the distance between cluster I and IX (26.82), cluster I and X (24.22), cluster III and V (23.11) and cluster I and II (22.29) suggesting diversity between them and the genotypes in these cluster could be used as parents in hybridization programme. Cluster II had minimum $\mathrm{D}^{2}$ value (2.23) with cluster $X$ indicating the genotypes in these clusters to be close in genetic makeup. Intermediate or moderate inter-cluster divergence was observed between cluster I and VIII, cluster III and IV, cluster V and VII and cluster VII and IX. Within a certain limit, hybridization between the more diverged parents is expected to generate wide range of variability in segregation generations. Buu and Tuan (1989) also suggested use of diverse genotypes in the hybridization programme for getting transgressive segregants in rice.

Table 5 presents the relative contribution of different characters towards divergence. Vector I and vector II values were obtained from principal component analysis. In first axis vector I, among the 12 studied characters, three characters such as growth duration, \% sterility and \% yield reduction having positive impact towards divergence. In vector II, four characters such as filled grain weight, TGW, 
Table 4. Average inter- and intra- (bold) cluster distance $\left(D^{2}\right)$ for 175 rice genotypes.

\begin{tabular}{ccccccccccc}
\hline Cluster & I & II & III & IV & V & VI & VII & VIII & IX & X \\
\hline I & $\mathbf{1 . 2 4 7 9}$ & & & & & & & & & \\
II & 22.29 & $\mathbf{0 . 9 5 5 3}$ & & & & & & & & \\
III & 7.43 & 14.97 & $\mathbf{1 . 0 6 7 7}$ & & & & & & & \\
IV & 20.31 & 2.38 & 13.02 & $\mathbf{0 . 8 5 6 3}$ & & & & & & \\
V & 30.42 & 8.38 & 23.11 & 10.41 & $\mathbf{1 . 1 0 9 1}$ & & & & & \\
VI & 18.08 & 4.36 & 10.76 & 2.59 & 12.57 & $\mathbf{0 . 9 6 3 6}$ & & & \\
VII & 11.34 & 11.05 & 4.04 & 9.10 & 19.28 & 6.87 & $\mathbf{1 . 2 6 7 3}$ & & \\
VIII & 14.91 & 7.59 & 7.58 & 5.63 & 15.81 & 3.43 & 3.71 & $\mathbf{0 . 9 2 6 4}$ & \\
IX & 26.82 & 4.78 & 19.49 & 6.59 & 4.27 & 8.87 & 15.59 & 12.08 & $\mathbf{0 . 7 9 1 8}$ & \\
X & 24.22 & 2.23 & 16.89 & 4.00 & 6.56 & 6.25 & 12.99 & 9.46 & 2.76 & $\mathbf{1 . 0 0 3 5}$ \\
\hline
\end{tabular}

$\mathrm{HI}$ and \% yield reduction having positive impact towards divergence. The characters that showed positive value in both the vectors contributed most towards divergence. In this study, \% yield reduction contributed most for divergence in the studied genotypes than the other characters. The character contributing maximum to the divergence are given greater emphasis for deciding on the cluster for the purpose of further selection and the choice of parents for hybridization (Jagadev et al., 1991). Abd Allah et al. (2010) found that number of panicles per plant, TGW, number of filled grains per panicle and panicle weight should be improved in order to increase grain yield under both normal and drought condition.

Table 5. Relative contribution of 12 morpho-physiological characters towards total divergence in rice genotypes.

\begin{tabular}{lcc}
\hline Character & Vector I & Vector II \\
\hline Growth duration (day) & 0.1708 & -0.2818 \\
Plant height (cm) & -0.1113 & -0.1915 \\
Tiller no./plant & -0.0502 & -0.5361 \\
Panicle no./plant & -0.0670 & -0.5348 \\
Panicle length (cm) & -0.1736 & -0.0948 \\
Filled grain (no./plant) & -0.4056 & -0.1425 \\
\% sterility & 0.3686 & -0.0036 \\
Filled grain wt (g/plant) & -0.4802 & 0.0136 \\
TGW (g) & -0.0120 & 0.1131 \\
Straw wt (g/plant) & -0.0361 & -0.4264 \\
HI & -0.4312 & 0.2930 \\
$\%$ yield reduction & 0.4504 & 0.0222 \\
\hline
\end{tabular}

From the results of cluster analysis, inter-cluster distance and mean value of studied characters especially yield and yield components under drought stress condition it was observed that cluster I included the most tolerant genotypes and cluster $\mathrm{V}$ included the sensitive genotypes. So based on the performance of genotypes under drought stress condition 10 clusters could be classified accordingly (Table 6). Cluster I and III would be ranked as tolerant and obtained score 1 , cluster VII and VIII as moderately tolerant and obtained score 3, cluster IV and VI as intermediate and obtained score 5, cluster II and X as moderately sensitive and obtained score 7 and finally cluster $\mathrm{V}$ and IX as sensitive and obtained score 9.

\section{CONCLUSION}

Based on the results the inter-cluster distances was larger than intra-cluster distances suggesting wider genetic diversity among the Table 6. Tolerant score and remarks of 175 rice genotypes of 10 clusters.

\begin{tabular}{ccc}
\hline Cluster no. & Tolerant score & Remark \\
\hline I, III & 1 & Tolerant \\
VII, VIII & 3 & $\begin{array}{c}\text { Moderately } \\
\text { tolerant } \\
\text { Intermediate } \\
\text { IV, VI }\end{array}$ \\
II, X & 5 & Moderately \\
V, IX & 7 & sensitive \\
\end{tabular}


entries of different clusters but very similar within the cluster. From this study we can concluded that nine genotypes of cluster I namely Canthi bakla (BRRI Genebank Acc. No. 7279), Nizersail (BRRI Genebank Acc. No. 7281), Hashim (BRRI Genebank Acc. No. 7283), Uricheora (BRRI Genebank Acc. No. 7311), Goura Kajol (BRRI Genebank Acc. No. 7312), Chini Sail (BRRI Genebank Acc. No. 7343), Tall Biruin (BRRI Genebank Acc. No. 7355), Sakkar Khora (BRRI Genebank Acc. No. 7506) and Boaincha Biruim (BRRI Genebank Acc. No. 7573) were more tolerant to water stress that could be used as donor parent in hybridization programme.

\section{REFERENCES}

Abd Allah, A A, M H Ammar and A T Badawi. 2010. Screening rice genotypes for drought resistance in Egypt. J. Plant Breed. Crop Sci. 2 (7): 205-215.

BRRI (Bangladesh Rice Research Institute). 1991. Annual report for 1988. Bangladesh Rice Research Institute, Gazipur, Bangladesh, pp.1-104.

Buu, B C and T M Tuan. 1989. Genetic diversity in rice (Oryza sativa L.). Intl. Rice Res. News. 14(4): 6-7.

Digby, P N, Galway and P Lane. 1989. Genstat 5: A second course [Computer software], Oxford Sci. Publication, Oxford. pp.103-108.

Hanamaratti, N G, S K Prashanthi, P M Salimath, R R Hanchinal, H D Mohankumar, K G Parameshwarappa and S D Raikar. 2008. Traditional landraces of rice in Karnataka: Reservoirs of valuable traits. Curr. Sci. 94 (2): 242-247.

IRRI (International Rice Research Institute). 2008. Field managed screening for drought resistance in rice. International Rice Research Institute, Los Banos, Manila, Philippines. 24p.
Jagadev, P N, K M Shamal and L Lenka. 1991. Genetic divergence in rape mustard. Indian J. Genet. Plant Breed. 51: 465-466.

Jager, M I, D Garethojones and E Griffith. 1983. Component of partial resistance of wheat seedling to Septoria nodorum. Euphytica. 32: 575-584.

Li, Z K, R Lafitte, C H M Vijayakumar, B Y Fu, Y M Gao, J L Xu, J Ali, M F Zhao, S B Yu, J Domingo, R Maghirang, G S Khush, D Mackill. 2004. Developing high yield and drought tolerant rice cultivars and discovering the complex genetic network underlying drought tolerance in rice. In: Proceeding of International Workshop on 'Resilient Crops for Water Limited Environments', 24-28 May 2004, CIMMYT, Mexico. pp. 222-124.

Mahalanobis, P C. 1936. On the generalized distance in statistics. Proc. Natl. Inst. Sci. India, 2: 49-55.

Pervin, M S. 2015. Screening of rice genotypes based on morpho-physiological characters under drought stress at reproductive phase. PhD Thesis, Department of Crop Botany, Bangladesh Agricultural University, Mymensingh, Bangladesh.

Rahman, M M, M S Islam, M G Rasul, M M Kadir and M H R Sheikh. 1998. Genetic divergence in wheat (Triticum aestivum L.). Bangladesh J. Plant Breeding and Genetics. 11 (1 \& 2): 19-21.

Reyners, F N, L Troung-Binh, T Jacquinot and R Nicou. 1982. Breeding for drought resistance in dry land rice. In: Drought Resistance in Crops with Emphasis on Rice. Int. Rice Res. Inst., Los Banos, Laguna, Philippines. pp. 273-292.

Tuong, T P, K T Ingram, J D Siopongco, R B Confesor, A A Boling, U Singh and M C S Wopereis. 1995. Performance of dry-seeded rainfed lowland rice in response to agro-hydrology and $\mathrm{N}$-fertilizer management. In: Ingram, K T (Editor), Rainfed Lowland Rice. Agricultural Research for High-Risk Environment. IRRI, Manila, Philippines.

Yoshida, S. 1981. Fundamentals of rice crop science. International Rice Research Institute, Los Banos, Laguna, Philippines, 269p. 